\title{
Fine and Coarse Components in Surface Sediments from Bikini Lagoon
}

\author{
V.E. Noshkin \\ R.J. Eagle \\ W.L. Robison
}

January 1997

This is an informal report intended primarily for internal or limited external distribution. The opinions and conclusions stated are those of the author and may or may not be those of the Laboratory.

Work performed under the auspices of the U.S. Department of Energy by the Lawrence Livermore National Laboratory under Contract W-7405-ENG-48. 


\section{DISCLAIMER}

This document was prepared as an account of work sponsored by an agency of the United States Government. Neither the United States Government nor the University of California nor any of their employees, makes any warranty, express or implied, or assumes any legal liability or responsibility for the accuracy, completeness, or usefulness of any information, apparatus, product, or process disclosed, or represents that its use would not infringe privately owned rights. Reference herein to any specific commercial product, process, or service by trade name, trademark, manufacturer, or otherwise, does not necessarily constitute or imply its endorsement, recommendation, or favoring by the United States Government or the University of California. The views and opinions of authors expressed herein do not necessarily state or reflect those of the United States Government or the University of California, and shall not be used for advertising or product endorsement purposes.

This report has been reproduced directly from the best available copy.

Available to DOE and DOE contractors from the Office of Scientific and Technical Information P.O. Box 62, Oak Ridge, TN 37831

Prices available from (423) 576-8401

Available to the public from the National Technical Information Service

U.S. Department of Commerce 5285 Port Royal Rd. Springfield, VA 22161 
Fine and Coarse Components in Surface Sediments from Bikini Lagoon.

\author{
Victor E. Noshkin \\ Rodney J. Eagle ${ }^{1}$ \\ William L. Robison \\ Lawrence Livermore National Laboratory \\ Livermore, CA
}

1 Retired. Present address Redding, CA. 


\section{Abstract}

In 1979, 21 years after the moratorium on nuclear testing in the Marshall Islands, surface sediment samples (to depths of 2 and $4 \mathrm{~cm}$ ) were collected from 87 locations in the lagoon of Bikini Atoll, one of the two sites in the Marshall Islands used by the United States to test nuclear devices from 1946 through 1958. The main purpose for the collections was to map the distribution of long-lived man-made radionuclides associated with the bottom material. In addition the samples were processed to estimate the fraction of fine and coarse components to show, by comparison, what modifications occurred in the composition since the sediments were first described in samples collected before testing in 1946. Nuclear testing produced more finely divided material that is now found in the surface sediment layer over large areas of the lagoon and especially in regions of the lagoon and reef adjacent to test sites. The 5 cratering events alone at Bikini Atoll redistributed sufficient material to account for the higher inventory of fine material found over the surface $4 \mathrm{~cm}$ of the sediment of the lagoon. Although the fraction of fine material in the bottom sediments was altered by the nuclear events, the combined processes of formation, transport and deposition were not sufficiently dynamic to greatly change the general geographical features of the major sedimentary components over most of the lagoon floor. 


\section{Introduction}

A large scientific investigation of the natural environment of Bikini Atoll, located in the northern Marshall Islands at about $11^{\circ} 36^{\prime} \mathrm{N}, 165^{\circ} 22^{\prime} \mathrm{E}$, was undertaken in the spring of 1946 (Emery et al. 1954) prior to testing the first U.S. nuclear device at the Pacific Proving Grounds. One study described the distribution of the different components that made up the lagoon sediment. This was accomplished by collecting numerous bottom surface sediment samples from the lagoon. In the laboratory the percentage of the various components was estimated in about 900 samples. The chief components included Foraminifera, coral, skeletal remains of Halimeda algae, and shells of mollusks. Material finer than about on-half a millimeter was not identified and grouped together as fine debris. Other minor components, too rare to justify percentage estimates, included Lithothamnion and other corallline algae, echinoid spines, sponge spicules, and bryozoans. Maps showing the percentage Foraminifera, Halimeda debris, fine debris and

shells in the surface sediments were constructed (Emery et al. 1954) to describe the distribution of major components in the pre-test natural sedimentary environment.

Subsequently, 23 nuclear tests were detonated between 1946 and 1958 at Bikini Atoll.

Each nuclear event contributed different quantities of radioactive fission products, some particle induced radionuclides and unspent nuclear fuel to the environment. These radionuclides became associated with the solid 
material incorporated into the fireball of the explosions and, depending on environmental and blast conditions, were transported to the troposphere and/or stratosphere and were subsequently deposited as local, intermediate range and global fallout. Some local fallout was deposited on islands of Bikini and to the surface of lagoon. Much of the fine pulverized material eventually settled to the surface of the bottom sediments. Internal waves, generated by surface explosions over water, moved sedimentary material previously deposited near test sites to different regions within and out of the Atoll. These man-made and some natural processes, such as normal circulation, erosion, tropical storms and typhoons, altered the natural distribution and relative abundance of the fine material and other sedimentary components in the surface of the lagoon sediment.

In 1979, 21 years after the moratorium on testing in the Marshall's, surface sediment samples (to depths of 2 and $4 \mathrm{~cm}$ ) were collected from 87 locations over the floor of the lagoon. The main purpose for the collections was to map the distribution of long-lived man-made radionuclides associated with the bottom material. The samples were also used to estimate the fraction of fine and coarse components in the sediment from the different locations sampled.

During the late 1970 's and early 1980 's, these sediment studies were assigned a low priority compared to programs that complemented clean-up at Enewetak Atoll ; a large radiological survey of several other Northern Marshall Island Atolls ; and resettlement considerations for Bikini Atoll. As a 
result the sediment data were set aside to assess at a later date. In 1984 the support for the marine studies in the Marshall's was terminated.

Consequently, the results and the sediment data from the 79 program remained unpublished. Now there appears to be a requirement for sediment information since plans for the resettlement at Bikini Atoll call for dredging lagoon sediments to build causeways and replace some soils on specific islands. Present support and facilities at the Atoll are not adequate to resample the entire lagoon bottom for new surface sediment samples. Information on radionuclide activity levels in, and the composition of, the sedimentary material will assist in determining locations to dredge material from the lagoon. In this report we describe the spatial distribution of fine material and other surface sediment components and compare these results with those of Emery et al. (1954) to show what modifications occurred since the sediments were described at a time prior to testing any nuclear devices at Bikini Atoll.

\section{Materials and Methods}

\section{Nuclear Testing at Bikini Atoll}

The names of the individual tests and the regions where the tests were exploded are shown in Figure 1. Seventeen devices were exploded from barges anchored in the lagoon or on the reef. Two were airburst detonations; one explosion was under water; and three were surface explosions on coral soil or the reef. The 23 tests were exploded at essentially 7 sites within the Atoll. Table 1 provides some information extracted from Cieceo and Nordyke 
(1964), Hawthorne (1979) and Lawson (1996) on each test exploded at the 7 regions. It is seen that many explosions occurred over ground zero locations of previous tests. In the region of the Bravo crater, for example, all 5 subsequent tests in the area (see Table 1) were conducted from barges anchored within a radius of $65 \mathrm{~m}$ from Bravo ground zero. The radius of the Bravo crater is 912 meters. Therefore even the Poplar event, the last test in this region, (see Table 1) was detonated approximately 80 meters from the outer rim of Bravo crater. Approximately half of the total effective energy generated at Bikini over the entire nuclear testing program occurred in the region of Bravo crater. The cratering events (see Table 1) vaporized and resuspended considerable material to the atmosphere that eventually fell to earth including the local environment.

\section{Sampling and Techniques}

In 1979 a portable winch powered by a gasoline engine was used to lower and raise a Shipek grab sampler. Sampling locations were preselected using a systematic sampling plan treating the Atoll as a square grid to insure all regions of the lagoon were sampled. Stations were separated approximately by 1.5 nautical miles in both latitude and longitude. We deviated from this grid only when the overlying water depth at a station was too shallow for the research vessel or when the bottom material encountered was to difficult to sample. Upon reaching a designated site, the vessel stopped and the Shipek was lowered at a slow rate to the lagoon bottom. At some locations it was necessary to lower the Shipek repeatedly before an adequate 
sample was obtained. Penetration to depths in surface sediment was poor in areas containing high percentages of coarse sediments, shell fragments, and remains of species of Halimeda algae, and best in areas in which the bottom sediment consisted of fine-grained material. The contents of the grab were sub-sampled to depths of 2 and $4 \mathrm{~cm}$ with end caps and a short core. The volume of material sampled with one end cap to $2 \mathrm{~cm}$ was $39.3 \mathrm{~cm}^{3}$. Usually 2-3 surface subsamples were removed from each grab and combined as a sample for that station. The volume sampled to $4 \mathrm{~cm}$ with the short core was $102.1 \mathrm{~cm}^{3}$. The core was obtained after the $2 \mathrm{~cm}$ subsamples were removed from the grab. This subsampling technique provided 2 series of dimensionally comparative surface sediment samples.

All samples were placed in plastic bags, frozen, and returned to the laboratories for processing and analysis. At LLNL the wet weight was determined and then the samples were sieved through a $0.5 \mathrm{~mm}$ screen to separate the less than $0.5 \mathrm{~mm}$ fraction from the coarse components. Each fraction was dried and weighed and the fraction of fine material in the total dry sample was determined. The amount of Halimeda remains, shell fragments, and foraminifera in the coarse fraction was estimated.

\section{Results}

Table 2 contains measurements of the percentage fine material; Foraminifera; Halimeda; and shell fragments in the 0-2 cm surface sediments samples collected in 1979. The last two columns contain the percent fine material in the $0-4 \mathrm{~cm}$ section of surface sediment and the ratio for the 
fraction of fine material in the $0-2 \mathrm{~cm}$ section relative to the fine material in the $0-4 \mathrm{~cm}$ section. Values for the quotient range from 0.2 to 1.8 and average 0.96 so that on the average, the same, or slightly smaller, fraction of fine material now extends from the sediment surface to a depth of at least $4 \mathrm{~cm}$ in the sediment column.

\section{Discussion}

\section{Distributions}

Emery et al., (1954) plotted the percent abundance of the major sedimentary components. Lines of equal abundance were drawn through the 25, 50 and $75 \%$ abundance values. The weighted average composition showed Halimeda debris most abundant (40\%), followed by fine debris (23\%), coral $(20 \%)$, Foraminifera (10\%), mollusk shells $(6 \%)$ and miscellaneous material (1\%). Plots showing the lines of equal abundance in Bikini lagoon for fine material and Halimeda remains are enlarged from the original Emery et al., (1954) report and are shown as Figures 2 and 3. Emery et al., (1954) indicated that off the beaches fine debris was present in appreciable quantities. Wave action broke the material near the beaches into fine debris that was carried up to $5 \mathrm{~km}$ into the lagoon. On the downwind side (western side) of the lagoon the area of most abundant fine debris was wide, irregular, and located further from shore than on the upwind side (eastern side). This pattern resulted from the greater wave action on the downwind side of the lagoon. The zone of fine debris appeared to be almost entirely absent along most of the upwind periphery from Aomoen island to Eneu island, except 
along Bikini island. Fine debris was less abundant near the middle of the lagoon, where it constitutes less than 10 percent of all components present in each sample (stated by Emery et al. 1954, but not shown in Figure 2), because the depth was too great for effective abrasion from waves and the distance from shore is too great for contributions from the beaches. The fine debris, therefore, had a ringlike distribution in the lagoon: open at the east end like a horseshoe.

There was an area of abundant Halimeda debris in middle and deeper part of the lagoon. Here the Halimeda segments made up at least $75 \%$ of each sample. The richest deposits were in the eastern half of the lagoon. Small regions of relatively low abundance of Halimeda generally coincided with the areas of abundant deeper-water Foraminifera. In water depths greater than about 55 meters, light was so reduced that live Halimeda plants do not flourish, or are absent. In these regions one still found remains of pulverized algae that originated at, and was transported from, shallower depths.

1979 Distributions

Figure 4 is developed from the results in Table 2 and shows the 25, 50 and $75 \%$ abundance lines for fine debris in the $0-2 \mathrm{~cm}$ section of surface sediment. Figure 5 shows the lines for comparable abundance of Halimeda remains in the 1979 surface sediments. Many general features described by Emery et al. (1954) are also apparent in the 1979 distributions. Highest amounts of fine debris are still evident off the beaches and the most abundant deposits are on the upwind side of the lagoon. The smallest fractions are still 
found in the middle of the lagoon but the area now defined by the $25 \%$ contour line is smaller than in 1946. There appears now to be higher percentages of fine material at downwind and northern lagoon locations that are coincident with the major test locations shown in Figure 1. The mean $\%$ of fine material is given in Table 3 and the regions bounded by lines of comparable abundance are shown in Figure 4. The area and fraction of the lagoon area of each section is also shown. The mean $\%$ of fine material in the surface layer of the lagoon sediment is computed from these values. It is estimated that the 1979 fine components now occupy $41 \pm 3 \%$ of the lagoon surface sediments compared to $23 \%$ estimated from the 1946 samples. The $\%$ of the lagoon floor occupied by coral-shell fragments, Foraminifera, and Halimeda decreased accordingly to 17,13 , and $28 \%$ in 1979. However the general features for Halimeda debris abundance, shown in Figure 5, are somewhat similar to those described for the 1946 samples in Figure 3. Lowest amounts are around the inner perimeter of the lagoon with abundances of $25 \%$ to $75 \%$ occupying the central section of the lagoon. The area defined by the 50 and $75 \%$ abundance lines for Halimeda are now substantially smaller than the area occupied in 1946 due to the higher percentage of fine material now found in the region. However the 1979 data no longer suggests any richer deposits in the eastern half of the lagoon as Emery et al, (1954) found in 1946.

Bikini lagoon has an area of $6.29 \mathrm{E}+08 \mathrm{~m}^{2}$. The volume of sedimentary material to depths of 2 and $4 \mathrm{~cm}$ are $1.3 \mathrm{E}+07$ and $2.6 \mathrm{E}+07 \mathrm{~m}^{3}$, respectively. In 
$1946,23 \%$ of the surface sediment, or $2.9 \mathrm{E}+06 \mathrm{~m}^{3}$ to $2 \mathrm{~cm}$ and $5.8 \mathrm{E}+06 \mathrm{~m}^{3}$ to 4 cm depth, was fine debris.

In 1979 it is estimated that $41 \%$ of the material in the lagoon surface sediment is now fine debris so that the volume of this material is now $5.1 \mathrm{E}+06 \mathrm{~m}^{3}$ to $2 \mathrm{~cm}$ and $10.3 \mathrm{E}+06 \mathrm{~m}^{3}$ to a depth of $4 \mathrm{~cm}$. There has been a net enrichment in fine debris of $2.2 \mathrm{E}+06$ and $4.5 \mathrm{E}+06 \mathrm{~m}^{3}$ over the first 2 and $4 \mathrm{~cm}$ depth of the surface sediment layers since 1946.

From the dimensions of the 5 craters given by Hawthorne (1979), and shown in Table 1, it is estimated that $1.25 \mathrm{E}+08 \mathrm{~m}^{3}$ of soil/sediment was suspended during the cratering events. The amount of new fine material, now found in the lagoon to depths of 2 and $4 \mathrm{~cm}$, represents 1.8 and 3.6\%, respectively, of the volume of fine material generated during the cratering events. Therefore the 5 cratering events alone generated sufficient material to account for the inventory of new fine material found over the surface $2-4 \mathrm{~cm}$ of the floor of the lagoon. This assumes no contribution of any solid material from barge events which is difficult to imagine. Therefore nuclear testing did increase (nearly doubled) the fraction of fine debris over the floor of the lagoon. This necessarily reduced the fractional contribution of the other major sedimentary components in surface layers from regions of the lagoon. Some amount of test-derived fine material must also be distributed to greater depths in the sediment column. However there is little data available to make a reasonable estimate of the inventory of new material deeper than 4 $\mathrm{cm}$. 
In 1972, sediment and water samples were obtained from within Bravo Crater aboard the R.V. Palumbo from the Puerto Rico Nuclear Center (Noshkin et al., 1997b; Schell, et al., 1980). The maximum depth of overlying water in the center of the crater at this time was 47 meters. If the estimate of 73 meters for the original bottom depth of the crater is correct, subsequent events coupled with redistribution processes and sedimentation, filled in the bottom 26 meters of the crater since it was formed in late February 1954. This fill amounts to $1.21 \mathrm{E}+07 \mathrm{~m}^{3}$ of fine sedimentary material and occupies approximately $13 \%$ of the original crater volume. Shell et al., (1980) found the ordering sequence of radionuclide concentrations in different sections of a 56 cm long core collected from the center of Bravo crater in 1972 differed greatly. They concluded that the radionuclides (and necessarily the sedimentary material) in the uppermost sections of sediment result from the post-Bravo tests conducted in the area. Thus a mixture of sediments labeled with radionuclides from different tests have settled over time to partially fill the original crater. The volume of fill also represents a small fraction of the material generated in the cratering events alone.

\section{Conclusions}

Nuclear testing altered (increased) the fraction of finely divided material now found in the surface sediment layer over large areas of the lagoon and especially in regions of the lagoon and reef adjacent to test sites. The increased fraction of fine material resulted from several processes including (1) direct fallout of material to the lagoon surface and subsequent 
deposition to the bottom sediments; (2) transport from reef flats initiated by internal waves generated during the explosions; and (3) resuspension of deposited ejecta from the nearby reefs or shallow regions and transport to other regions within the lagoon by natural processes. Although the fraction of fine material in the bottom sediments was altered by the nuclear events, the combined processes of formation, transport and deposition were not sufficiently dynamic to greatly alter the general geographical features of the major sedimentary components such as fine debris and Halimeda remains over most of the lagoon floor.

\section{Acknowledgments}

The authors acknowledge the assistance of Mr. K. V. Marsh and Mr. J. Schweiger in collecting lagoon sediment samples. The work was performed under the auspices of the U. S. Department of Energy under contract number W-7405-Eng-48. 


\section{LITERATURE CITED}

Circeo, L. J., JR., and M. D. NordyKe. 1964. Nuclear Cratering Experience at the Pacific Proving Grounds, USAEC Report UCRL-12172, Lawrence Livermore Laboratory, Livermore, CA.

EMERY, K.O., J. I. TRACY, and H. S. LADD. 1954. Geology of Bikini and Nearby Atolls, Professional Paper 260-A, U. S. Geological Survey, U.S. Gov. Printing Office, Wash. D.C. 263 pp.

Hawthorne, H. A. 1979. Compilation of Local Fallout Data from Test Detonations 1945-1962 Extracted From DASA 1251, Vol. II-Oceanic U.S. Tests, Report DNA 1251-2-EX, Defense Nuclear Agency, Wash. D.C. 333 pp.

LAWSON J.E., JR. 1996. Catalog of Known and Putative Nuclear Explosions from Unclassified Sources, http://www.pal.xgw.fi/hew/CATALOG, Oklahoma Geol. Survey Observatory, Leonard, OK. (modified 5 Aug. 1996).

SCHELL, W.R., F.G. LOWMAN, and R.P MARSHALL. 1980. Geochemistry of Transuranic Elements at Bikini Atoll. in Transuranic Elements in the Environment, W.C. Hansen, Ed. U.S. Dept. of Energy, Wash. D.C. Rept (DOE/TIC-22800). 
Table 1. Test Site Data and Crater Dimensions

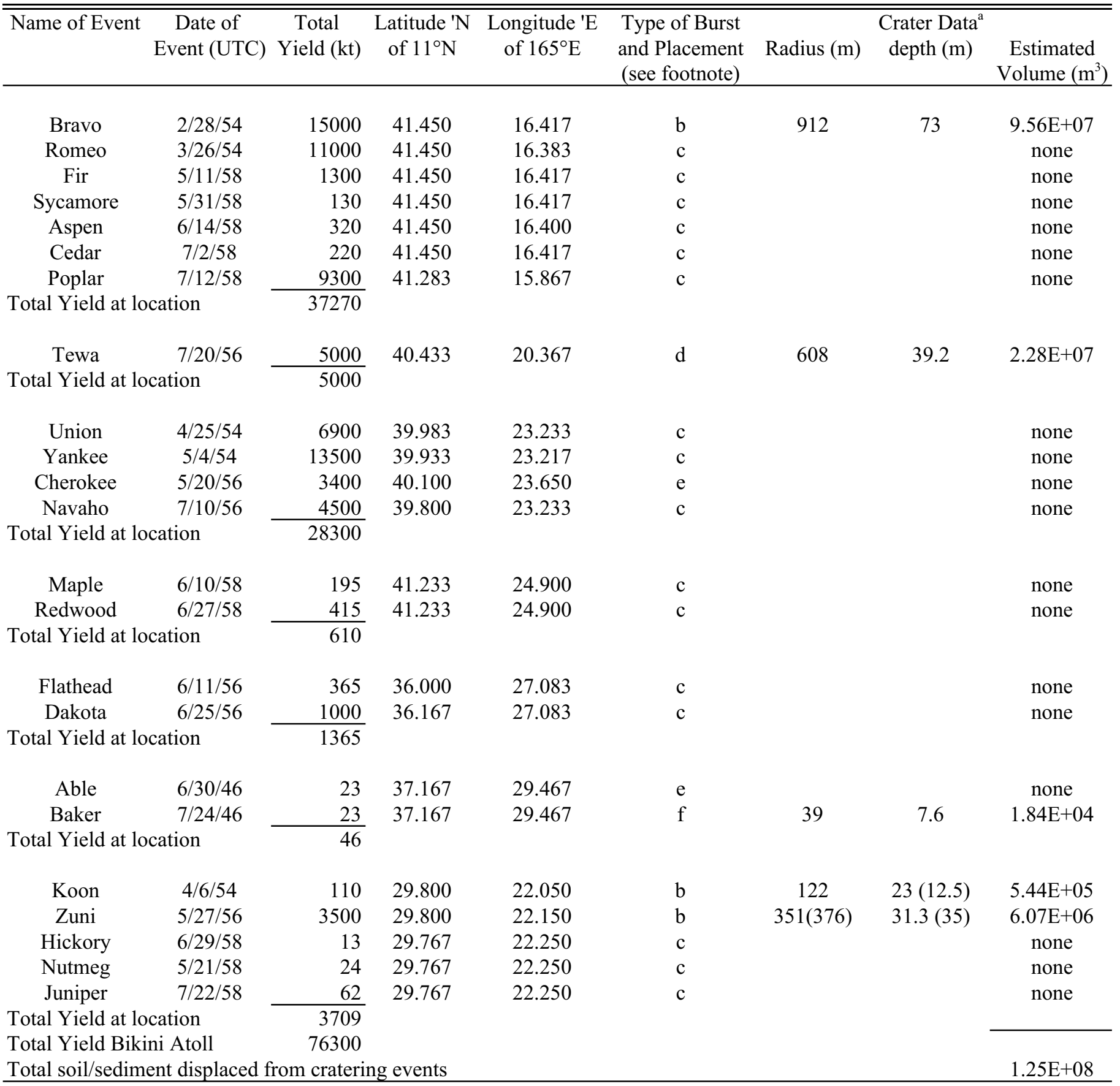

a-estimated assuming crater resembles a spherical segment $\left(\mathrm{V}=0.1667 * \pi * \mathrm{~d}^{*}\left(3 * \mathrm{r}^{2}+\mathrm{d}^{2}\right)\right.$ where $\mathrm{r}$ is the radius and $d$ is the depth in meters. $R$ and $d$ values from Hawthorne (1979); Circeo and Nordyke (1964). Values for $r$ and d differ for Koon and Zuni. Circeo \& Nordyke values shown in parenthesis. Volume computed using values from Hawthorne. b-Surface burst from platform on coral soil.

c-surface burst from barge over deep water.

d-Surface burst from barge on water (7.6 $\mathrm{m}$ to bottom).

e-Air burst over water.

f-Underwater $27 \mathrm{~m}$ above lagoon floor.

NOTE: 1 minute or 60 seconds of latitude for Bikini(or longitude) is taken equal to 1 nautical mile or 1853 meters.

Therefore 0.1 minute of latitude (or longitude) is equivalent to a distance of 06 seconds or 185.3 meters. 
Table 2. Description of Major Materials in Bikini Lagoon Surface Sediment Collected during 4-6/1979.

\begin{tabular}{|c|c|c|c|c|c|c|c|}
\hline $\begin{array}{c}\text { Minutes } \\
\text { east of } 165^{\circ} \mathrm{E} \\
\mathrm{X} \text { coord }\end{array}$ & $\begin{array}{c}\text { Minutes } \\
\text { North of } 11^{\circ} \mathrm{N} \\
\mathrm{Y} \text { coord }\end{array}$ & $\begin{array}{c}0-2 \mathrm{~cm} \% \text { fine } \\
\text { material } \\
\text { by wt }\end{array}$ & $\begin{array}{c}0-2 \mathrm{~cm} \% \text { shells- } \\
\text { coral } \\
\text { by wt }\end{array}$ & $\begin{array}{l}0-2 \mathrm{~cm} \\
\% \text { forams } \\
\text { by wt }\end{array}$ & $\begin{array}{c}0-2 \mathrm{~cm} \\
\% \text { Halimeda } \\
\text { by wt }\end{array}$ & $\begin{array}{c}0-4 \mathrm{~cm} \% \text { fine } \\
\text { material } \\
\text { by wt }\end{array}$ & $\begin{array}{c}\text { ratio fines } \\
0-2 \mathrm{~cm} / 0-4 \mathrm{~cm}\end{array}$ \\
\hline 33.5 & 31 & 75 & 10 & 8 & 6 & & \\
\hline 32.5 & 30 & 18 & 73 & 3 & 7 & & \\
\hline 32.5 & 31.5 & 47 & 27 & 23 & 3 & 54 & 0.87 \\
\hline 32.5 & 33 & 42 & 35 & 6 & 16 & 42 & 1.00 \\
\hline 32.5 & 34.5 & 30 & 18 & 11 & 41 & 37 & 0.81 \\
\hline 32.5 & 36 & 89 & 4 & 4 & 3 & & \\
\hline 31 & 37.5 & 19 & 9 & 4 & 68 & & \\
\hline 28 & 37.5 & 34 & 14 & 10 & 42 & & \\
\hline 26.5 & 37.5 & 17 & 22 & 24 & 37 & 21 & 0.81 \\
\hline 26.5 & 36 & 6 & 7 & 15 & 72 & 6 & 1.08 \\
\hline 28 & 36 & 8 & 6 & 18 & 68 & 8 & 0.95 \\
\hline 29.5 & 36 & 10 & 10 & 32 & 48 & 6 & 1.69 \\
\hline 31 & 36 & 59 & 9 & 10 & 21 & & \\
\hline 29.5 & 34.5 & 38 & 11 & 23 & 28 & 39 & 0.98 \\
\hline 29.5 & 33 & 23 & 12 & 33 & 32 & 29 & 0.80 \\
\hline 29.5 & 31.5 & 41 & 31 & 10 & 18 & 48 & 0.85 \\
\hline 26.5 & 31.5 & 42 & 33 & 10 & 16 & 51 & 0.82 \\
\hline 26.5 & 33 & 13 & 11 & 24 & 52 & 17 & 0.74 \\
\hline 26.5 & 34.5 & 6 & 4 & 18 & 72 & 10 & 0.62 \\
\hline 25 & 34.5 & 22 & 20 & 22 & 37 & 29 & 0.75 \\
\hline 23.5 & 34.5 & 3 & 6 & 7 & 84 & 5 & 0.60 \\
\hline 22 & 34.5 & 13 & 10 & 29 & 49 & 17 & 0.75 \\
\hline 20.5 & 34.5 & 11 & 14 & 5 & 70 & 8 & 1.35 \\
\hline 19 & 34.5 & 50 & 19 & 12 & 18 & 55 & 0.91 \\
\hline 17.5 & 34.5 & 59 & 24 & 12 & 6 & & \\
\hline 16 & 34.5 & 77 & 11 & 10 & 3 & 76 & 1.01 \\
\hline 14.5 & 34.5 & 65 & 11 & 15 & 8 & 65 & 1.00 \\
\hline 14.5 & 36 & 74 & 6 & 6 & 13 & 76 & 0.98 \\
\hline 16 & 36 & 24 & 15 & 14 & 46 & 15 & 1.59 \\
\hline 16 & 37.5 & 44 & 36 & 8 & 12 & & \\
\hline 17.5 & 39 & 78 & 8 & 8 & 6 & 79 & 0.99 \\
\hline 20.5 & 39 & 100 & 0 & 0 & 0 & 100 & 1.00 \\
\hline 19 & 40.5 & 52 & 7 & 3 & 38 & & \\
\hline 19 & 37.5 & 36 & 10 & 25 & 29 & 41 & 0.89 \\
\hline 19 & 36 & 13 & 42 & 26 & 19 & 14 & 0.89 \\
\hline 19 & 33 & 62 & 22 & 11 & 6 & 65 & 0.95 \\
\hline 19 & 31.5 & 63 & 18 & 13 & 5 & 60 & 1.05 \\
\hline 21.25 & 29.75 & 59 & 29 & 7 & 5 & 68 & 0.87 \\
\hline 33.3 & 30.9 & 96 & 2 & 1 & 1 & 97 & 0.99 \\
\hline 31 & 31.5 & 65 & 18 & 11 & 6 & 66 & 0.99 \\
\hline 28 & 31.5 & 57 & 22 & 8 & 13 & 60 & 0.95 \\
\hline 25 & 31.5 & 42 & 30 & 9 & 19 & 28 & 1.50 \\
\hline 23.5 & 31.5 & 13 & 13 & 16 & 57 & 32 & 0.42 \\
\hline 22 & 31.5 & 48 & 26 & 10 & 16 & 65 & 0.74 \\
\hline 20.5 & 31.5 & 38 & 35 & 8 & 19 & 43 & 0.89 \\
\hline 17.5 & 31.5 & 67 & 19 & 9 & 5 & 62 & 1.08 \\
\hline
\end{tabular}


Table 2. Description of Major Materials in Bikini Lagoon Surface Sediment Collected during 4-6/1979 (cont).

\begin{tabular}{|c|c|c|c|c|c|c|c|}
\hline $\begin{array}{l}\text { Minutes } \\
\text { east of } 165^{\circ} \mathrm{E} \\
\mathrm{X} \text { coord }\end{array}$ & $\begin{array}{l}\text { Minutes } \\
\text { North of } 11^{\circ} \mathrm{N} \\
\text { Y coord }\end{array}$ & $\begin{array}{c}0-2 \mathrm{~cm} \% \text { fine } \\
\text { material } \\
\text { by wt }\end{array}$ & $\begin{array}{c}0-2 \mathrm{~cm} \% \text { shells- } \\
\text { coral } \\
\text { by wt }\end{array}$ & $\begin{array}{l}0-2 \mathrm{~cm} \\
\% \text { forams } \\
\text { by wt }\end{array}$ & $\begin{array}{c}0-2 \mathrm{~cm} \\
\% \text { Halimeda } \\
\text { by wt }\end{array}$ & $\begin{array}{c}0-4 \mathrm{~cm} \% \text { fine } \\
\text { material } \\
\text { by wt }\end{array}$ & $\begin{array}{c}\text { ratio fines } \\
0-2 \mathrm{~cm} / 0-4 \mathrm{~cm}\end{array}$ \\
\hline 16 & 32.8 & 33 & 43 & 12 & 12 & 33 & 1.00 \\
\hline 17.5 & 32.8 & 59 & 20 & 10 & 11 & 61 & 0.96 \\
\hline 20.5 & 32.8 & 64 & 11 & 8 & 17 & 64 & 1.00 \\
\hline 22 & 32.8 & 45 & 18 & 12 & 25 & 49 & 0.93 \\
\hline 23.5 & 32.8 & 66 & 26 & 5 & 3 & 78 & 0.84 \\
\hline 25 & 32.8 & 24 & 12 & 14 & 49 & 28 & 0.87 \\
\hline 28 & 32.8 & 56 & 12 & 13 & 19 & 48 & 1.16 \\
\hline 28 & 34.3 & 12 & 11 & 24 & 53 & 32 & 0.39 \\
\hline 31 & 32.8 & 8 & 5 & 22 & 65 & 7 & 1.17 \\
\hline 31 & 34.3 & 6 & 4 & 14 & 76 & 29 & 0.22 \\
\hline 26.5 & 39 & 39 & 12 & 11 & 38 & & \\
\hline 25 & 39 & 90 & 4 & 2 & 4 & & \\
\hline 25 & 40.5 & 71 & 3 & 12 & 14 & & \\
\hline 23.5 & 40.5 & 50 & 7 & 14 & 28 & & \\
\hline 22 & 40.2 & 47 & 8 & 15 & 30 & & \\
\hline 20.5 & 40.2 & 86 & 2 & 2 & 10 & & \\
\hline 17.5 & 40.2 & 44 & 18 & 12 & 26 & 44 & 1.01 \\
\hline 16 & 40.2 & 100 & 0 & 0 & 0 & & \\
\hline 16 & 39 & 98 & 1 & 0 & 1 & 97 & 1.01 \\
\hline 14.5 & 39 & 95 & 1 & 3 & 2 & 96 & 0.98 \\
\hline 14.5 & 37.8 & 45 & 6 & 19 & 30 & 51 & 0.87 \\
\hline 17.5 & 37.7 & 22 & 12 & 26 & 40 & 30 & 0.74 \\
\hline 17.5 & 36 & 32 & 16 & 24 & 28 & 25 & 1.29 \\
\hline 20.5 & 36 & 8 & 4 & 19 & 69 & 29 & 0.27 \\
\hline 22 & 36 & 6 & 5 & 10 & 79 & 5 & 1.14 \\
\hline 23.5 & 36 & 8 & 6 & 37 & 49 & 13 & 0.63 \\
\hline 25 & 36 & 13 & 4 & 31 & 51 & 10 & 1.35 \\
\hline 25 & 37.7 & 10 & 10 & 25 & 55 & 6 & 1.60 \\
\hline 23.5 & 37.7 & 38 & 4 & 20 & 38 & 51 & 0.74 \\
\hline 22 & 37.7 & 9 & 4 & 20 & 67 & 11 & 0.80 \\
\hline 20.5 & 37.7 & 13 & 3 & 30 & 54 & 11 & 1.21 \\
\hline 22 & 39 & 48 & 11 & 8 & 32 & 60 & 0.80 \\
\hline 23.5 & 39 & 54 & 6 & 9 & 31 & 69 & 0.78 \\
\hline 31 & 30.1 & 16 & 65 & 12 & 7 & & \\
\hline 29.5 & 30.1 & 31 & 51 & 9 & 9 & 42 & 0.75 \\
\hline 28 & 30.1 & 14 & 80 & 3 & 3 & 11 & 1.29 \\
\hline 26.6 & 30.3 & 19 & 68 & 7 & 7 & 26 & 0.72 \\
\hline 25.2 & 30.3 & 46 & 31 & 4 & 19 & 52 & 0.88 \\
\hline 23.5 & 30.5 & 76 & 8 & 6 & 11 & 71 & 1.06 \\
\hline 22 & 30.1 & 67 & 3 & 3 & 27 & 43 & 1.56 \\
\hline 20.5 & 30.4 & 65 & 18 & 9 & 9 & 36 & 1.79 \\
\hline
\end{tabular}


Table 3. Percentage of Fine Material in Surface $2 \mathrm{~cm}$ Layer of 1979 Bikini Lagoon Sediments

\begin{tabular}{|c|c|c|c|}
\hline $\begin{array}{l}\text { Region described } \\
\text { by lines of equal } \\
\text { abundance }\end{array}$ & $\begin{array}{l}\text { Mean percentage } \\
\text { of fines in region }\end{array}$ & $\begin{array}{l}\text { Percentage of } \\
\text { lagoon area } \\
\text { covered with } \\
\text { fine material }\end{array}$ & $\begin{array}{c}\text { Percent } \\
\text { contribution } \\
\text { to amount } \\
\text { in entire } \\
\text { surface } \\
\text { layer }\end{array}$ \\
\hline $0 \%-25 \%$ & $13.1 \pm 5.9$ & 32.4 & $4.2 \pm 1.9$ \\
\hline $25 \%-50 \%$ & $40.5 \pm 5.6$ & 31.7 & $12.8 \pm 1.9$ \\
\hline $50 \%-75 \%$ & $61.1 \pm 6.5$ & 27.1 & $16.6 \pm 1.9$ \\
\hline \multirow[t]{2}{*}{$75 \%-100 \%$} & $88.2 \pm 9.7$ & 8.8 & $\underline{7.8 \pm 0.6}$ \\
\hline & \multicolumn{2}{|c|}{ Total \% Fines in Surface Layer } & $41.4 \pm 3.3$ \\
\hline
\end{tabular}




\section{Figure Captions}

Figure 1. Names and Locations of Nuclear Tests at Bikini Atoll.

Figure 2. Distribution and $\%$ abundance lines of fine material $(<0.5 \mathrm{~mm})$ in the surface of Bikini Lagoon Sediment Sampled in 1946.

Figure 3. Distribution and $\%$ abundance lines of the remains of Halimeda algae in the surface of Bikini Lagoon Sediment Sampled in 1946.

Figure 4. Station locations defined in Table 2 and $\%$ abundance lines of fine material $(<0.5 \mathrm{~mm})$ in the surface of Bikini Lagoon Sediment Sampled in 1979.

Figure 5. Station locations defined in Table 2 and $\%$ abundance lines of the remains of Halimeda algae in the surface of Bikini Lagoon Sediment Sampled in 1979. 


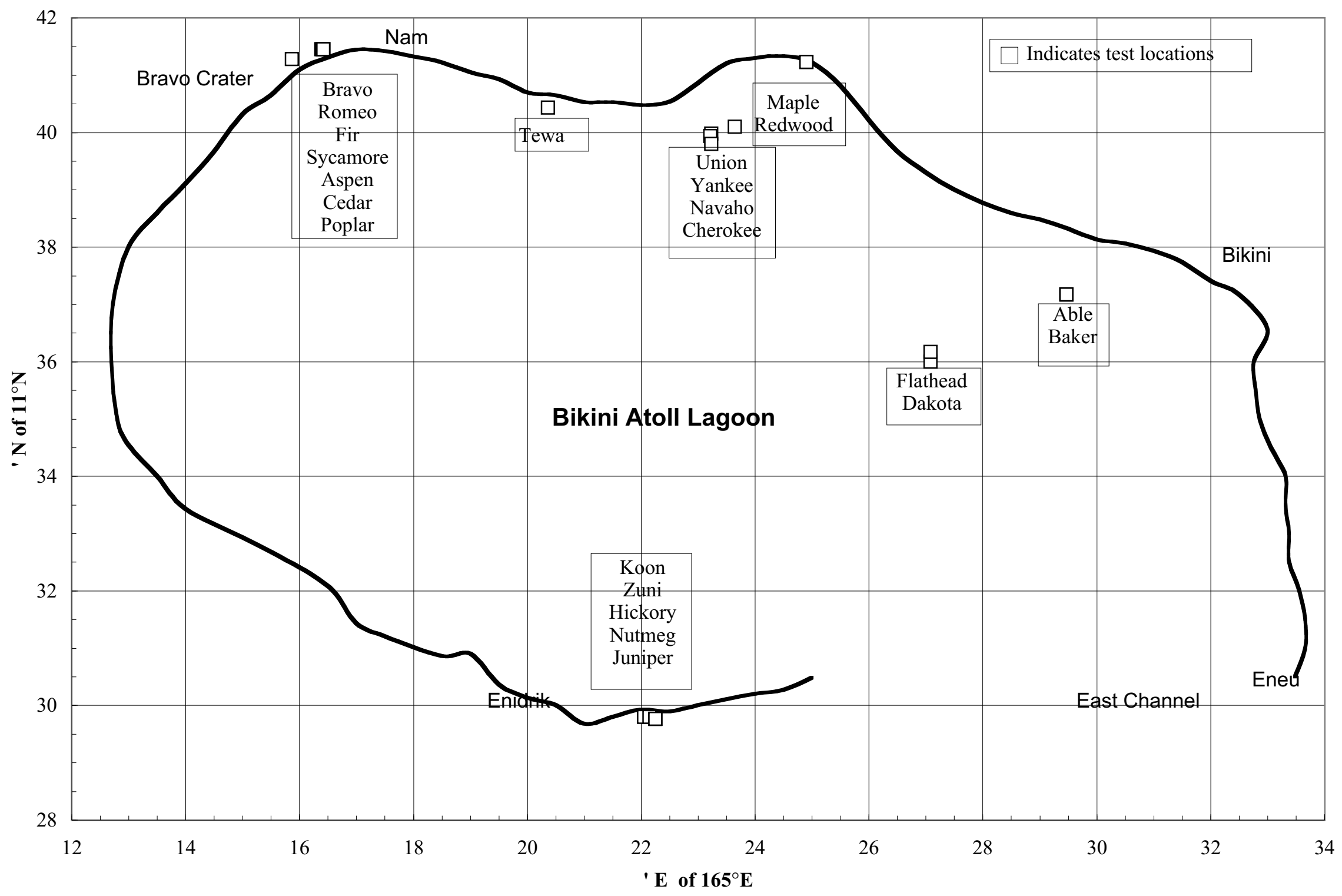




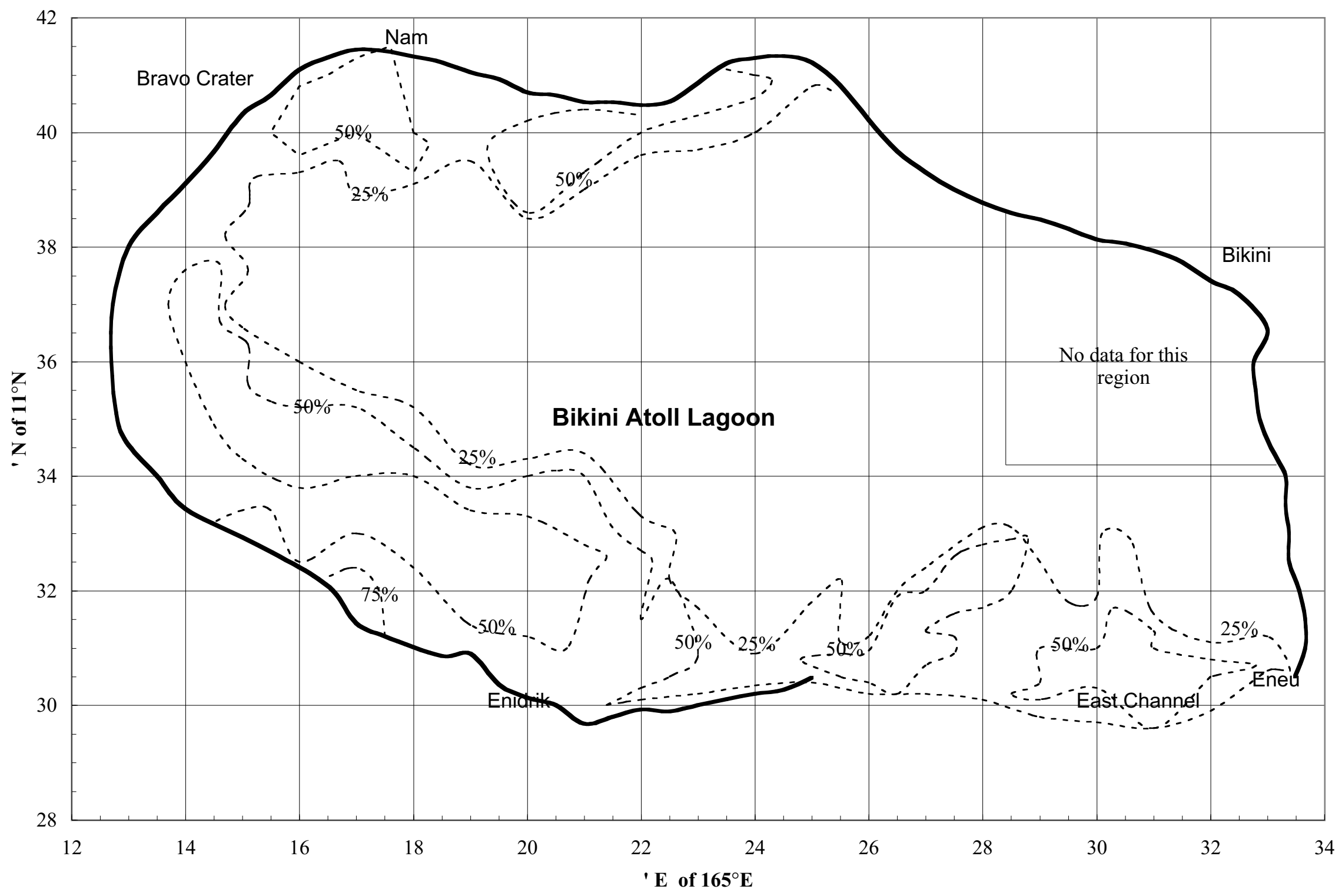




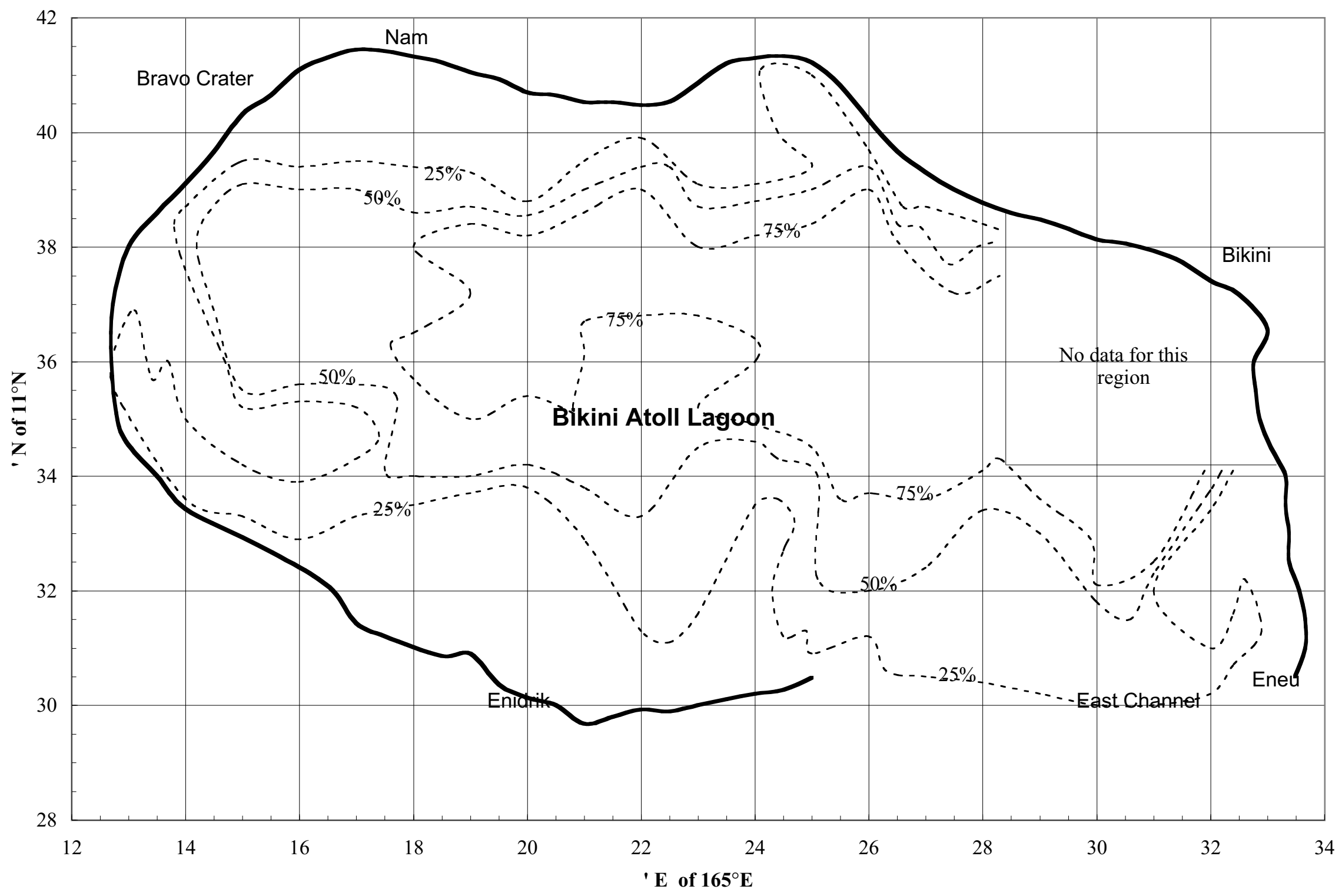




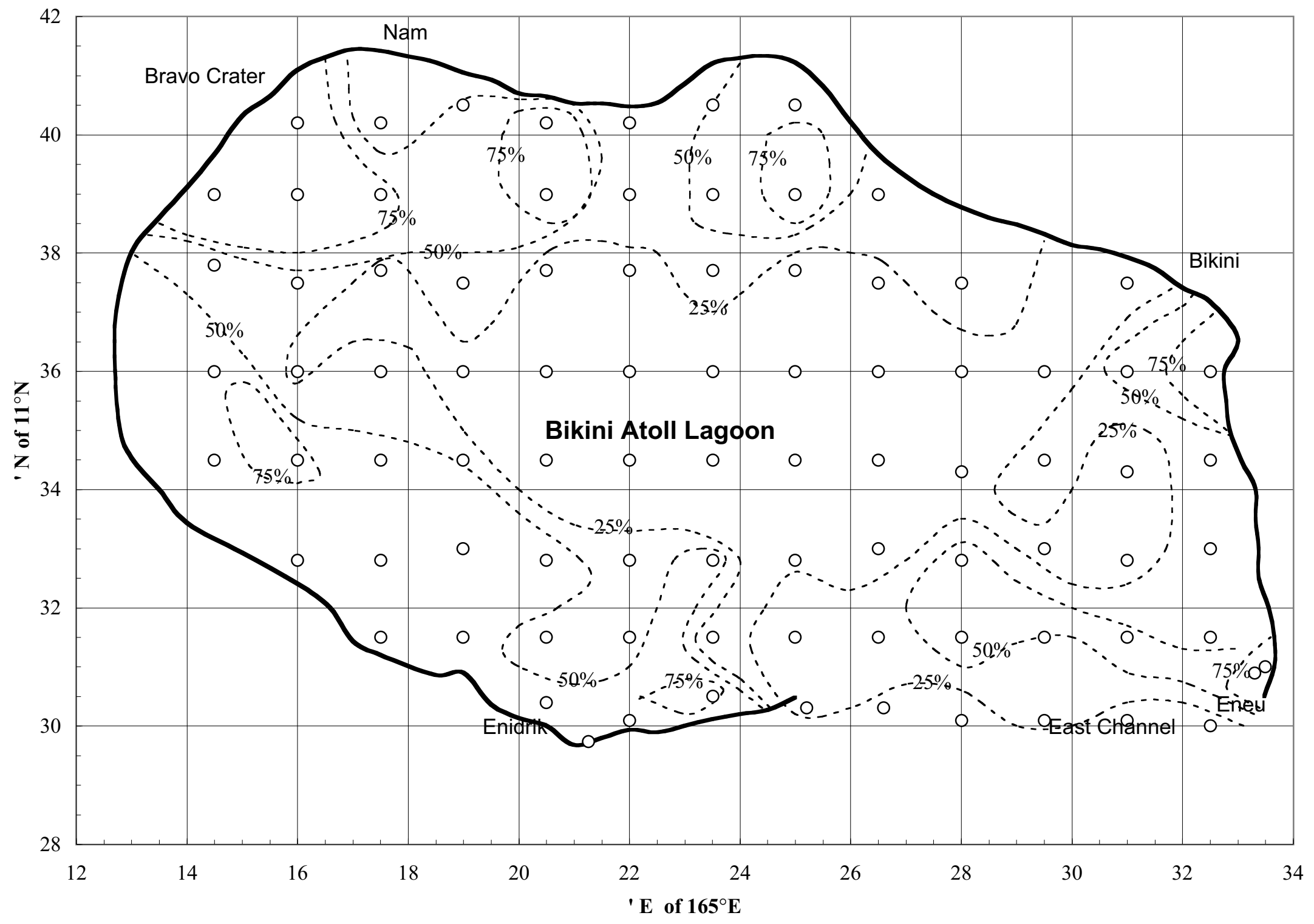




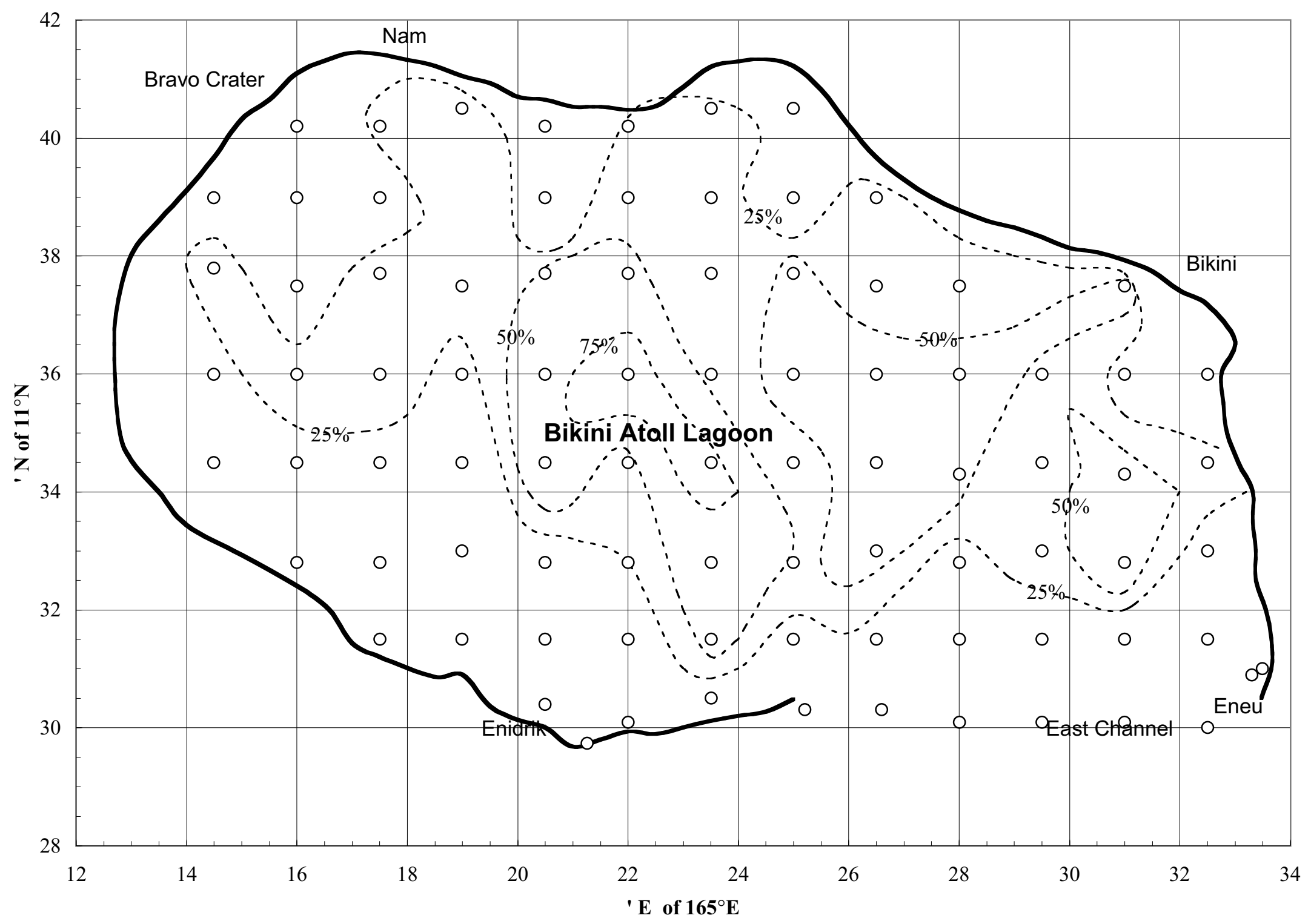




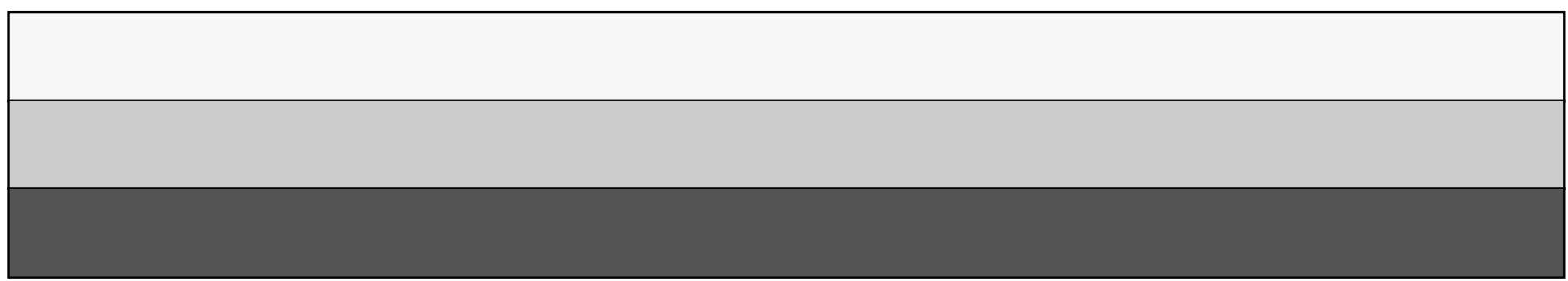

